\title{
Investigation of Some Biological Activities of Extracts Centranthus longiflorus subsp. longiflorus
}

\author{
Elif Ayar ${ }^{(i)}$, Nezahat Kandemir ${ }^{(i)}$ 2,, Sevket Kandemir ${ }^{(D 2}$, Umut Celikoglu ${ }^{(i)}$, \\ Onder Idil ${ }^{(D)}$
}

\author{
${ }^{1}$ Institute of Science and Technology, Amasya University, Amasya, TURKEY \\ ${ }^{2}$ Department of Mathematics and Science, Faculty of Education, Amasya University, Amasya, TURKEY \\ ${ }^{3}$ Department of Chemistry, Faculty of Science, Amasya University, Amasya, TURKEY \\ ${ }^{4}$ Department of Pre-school Education, Faculty of Education, Amasya University, Amasya, TURKEY
}

\begin{abstract}
In this study, the effects of above and below-ground extracts of Centranthus longiflorus subsp. longiflorus plant, commonly found in Turkey, on antioxidant, antimicrobial and DNA damage were evaluated. Plant extracts were prepared by applying three different solvents (hexane, methanol and ethanol). The antimicrobial activity tests of the extracts were performed using four different standard strains and one yeast. DPPH, total phenolic content calculation and CUPRAC methods were applied for antioxidant activity studies. Additionally, the effects of plant extracts on DNA damage were investigated using pBR322 plasmid DNA. According to the data obtained, especially the below-ground hexane (MIC value:375 $\mathrm{g} / \mathrm{mL}$ ) extract showed more antimicrobial activity than other plant extracts, and it was found to be more effective Gram negative bacteria. The highest antioxidant activity was determined in extracts prepared with above ( $\mathrm{IC}_{50}$ value of methanol extract: $4.5 \mathrm{mg} / \mathrm{mL})$ and below-ground $\left(\mathrm{IC}_{50}\right.$ value of methanol extract:5.7mg/mL) methanol. The above $(93,9 \mu \mathrm{g} \mathrm{GAE} / \mathrm{mL})$ and below-ground $(96.9 \mu \mathrm{g} \mathrm{GAE} / \mathrm{mL})$ methanol extracts were seen to have high total phenolic content. It has also been observed that above-ground hexane and methanol extracts have no effect on pBR322 plasmid DNA, but other extracts affect pBR322 plasmid DNA in the direction of degradation or deformation. Especially, the extracts of the above and below-ground ethanol had the effect of completely eliminating the open ring form. Therefore, it was concluded that this taxon could be widely used in the treatment and prevention of oxidative stress-related diseases in the future.
\end{abstract}

\section{ARTICLE HISTORY}

Received: December 18, 2019

Revised: February 25, 2020

Accepted: December 06, 2020

\section{KEYWORDS}

Antimicrobial,

Antioxidant,

Centranthus longiflorus, pBR322 plasmid DNA

\section{INTRODUCTION}

Centranthus DC. genus belongs to Caprifoliaceae family and there are 3 species called $C$. ruber (L.) DC, C. longiflorus Stev. and C. calcitrapa (L.) Dufr. in Turkey [1]. C. longiflorus subsp. longiflorus Stev. is a herbaceous, rhizomatous, perennial plant with 70-200 cm in length. It distributes in rocky slopes, bushes and heavy soils at altitudes of 0-2300 m. The flowers are

CONTACT: Nezahat Kandemir $\square$ nezahatkndmr@gmail.com Department of Mathematics and Science, Amasya, Turkey 
dark pink. In Turkey, it spreads widely in Northern, Southern and Central Anatolia regions and is called as red valerian. The above and below-ground parts of this plant are used as sedative and anxiolytic [2]. Also, it has a high invasive species property for meadow.

Medicinal plants in the world are natural antioxidant sources as they contain some secondary metabolites such as phenolic acids, flavonoids, cinnamic acid derivatives, coumarins, tocopherols and tannins [3-5]. Therefore, they are preferred as they prevent or treat many diseases in many parts of world. Free radicals play a role in the development of many diseases. Antioxidants protect the human body against diseases caused by free oxygen derivatives. Valepotriates, iridoids, patrinoside, kanokoside A, oleanolic acid, valerianic acid, sitosterol, chlorogenic and caffeic acid, essential oils, saponins, resins, alkaloids and coumarins are isolated from above and below-ground parts of Centranthus longiflorus subsp. longiflorus. So that, some researchers indicated that it could be used in the treatment of diseases related to oxidative stress in the future [4-11].

Secondary metabolites with antimicrobial properties are grouped as phytochemical alkaloids, terpenoids, essential oils, phenolics, lectins-polypeptides and polyacetylenes by Cowan [12]. On the other hand, Okunade and Elvin-Levis [13] classified them as alkaloids, flavones, polyphenols, steroids, terpenoids, peptides, chromones, saponins, phenols, coumarins and chalcones. Some phenols and alkaloids are the most important groups of plant-derived antimicrobial agents $[14,15]$. Secondary metabolites show the antimicrobial mechanism affecting the proteins and ion channels in the outer membrane of microorganisms. In particular, phenolic compounds inhibit different mechanisms in bacterial growth and are effective in the treatment of diseases caused by resistant strains [16]. DNA cleavage is an event that takes place in the cell throughout the natural process with enzymatic or oxidation processes. Besides, the goal of many anticancer drugs is to interact with DNA and trigger the cell apoptosis [17]. Therefore, the interaction of plant extracts and metal complexes with DNA is very important for the discovery of new drugs. Accordingly, we aimed to determine antioxidant, antimicrobial activities and effects on DNA damage of below and above-ground extracts of $C$. longiflorus subsp. longiflorus which are used traditionally in Turkey, in different organic solvents.

\section{MATERIAL and METHODS}

\subsection{Collection and Identification of Plants Samples}

Plant samples were collected during the flowering periods from the vicinity of Tortum Lake (Erzurum) and between Tortum-Oltu in 2014. The taxonomic description is based on Güner et al. [1] and Richardson [18]. The above and below-ground parts of plant samples were cut into small pieces and dried in the shade. Dried plant samples were stored in cloth bags until analyzed. Later, dried samples were milled and used for chemical analysis. Some of the plant samples also were made herbarium samples and deposited in the research laboratory of Faculty of Education, Amasya University, Turkey.

\subsection{Preparation of Extracts}

The below and above-ground parts of the subspecies were separated and extracted with Soxhlet apparatus by using different organic solvents. For this purpose, $100 \mathrm{~g}$ of plant samples were taken into Soxhlet cartridges and extracted with hexane, ethanol and methanol for $8 \mathrm{~h}$ [19]. The organic solvents evaporated under reduced pressure and the resulting extracts were stored at $-20{ }^{\circ} \mathrm{C}$ until analysis.

\subsection{Antioxidant Assay}

\subsubsection{Total Phenolic Compound Activity}

The amount of phenolic compounds of the plant extracts were determined as the gallic acid equivalent (GAE) with the method determined by Singleton and Rossi [20]. $100 \mu 1$ of the 
extract solution $(1 \mathrm{mg} / \mathrm{mL})$ were completed with methanol to $2.3 \mathrm{~mL}$ and $50 \mu \mathrm{l}$ of FolinCiocalteu reagent was added. After 3 min, $150 \mu \mathrm{l}$ of $2 \%$ (w/v) $\mathrm{Na}_{2} \mathrm{CO}_{3}$ solution was added and incubated for two hours at room temperature. The absorbance of the samples was read at 760 $\mathrm{nm}$ (Thermo Scientific Genesys 10S UV-VIS Spectrophotometer) against the blank, which did not contain a test sample. The results were expressed as $\mu \mathrm{g}(\mathrm{GAE}) / \mathrm{mL}$ (extract).

\subsubsection{DPPH Free Radical Scavenging Activity}

The antioxidant activities of the plant samples were evaluated by testing the DPPH free radical scavenging activity. Butylated hydroxy anisole (BHA) was used as a standard antioxidant. For this purpose, $50 \mu \mathrm{l}$ of different concentrations $(3-10 \mathrm{mg} / \mathrm{mL})$ of plant extracts were incubated with $2850 \mu 1$ of DPPH solution $\left(6 \times 10^{-5} \mathrm{M}\right)$ in dark and at room temperature for 30 minutes. At the end of this period, the absorbance was measured $517 \mathrm{~nm}$ against the blank sample [21]. The DPPH \% was calculated according to formula (I) and the results were expressed as $\mathrm{IC}_{50}$ value. $\mathrm{IC}_{50}$ refers to the concentration of plant at the moment when half of the DPPH amount was scavenging.

$$
\text { Inhibition } \%=\left(\mathrm{A}_{\mathrm{DPPH}} \cdot \mathrm{A}_{\text {sample }}\right) / \mathrm{A}_{\mathrm{DPPH}} \cdot \mathrm{X} 100
$$

Respectively, ADPPH refers to. the DPPH radical in the absence of plant extract and $\mathrm{A}_{\text {sample }}$ refers to the DPPH radical in the presence of plant extract absorbance (at $517 \mathrm{~nm}$ ).

\subsubsection{Cu (II) Reducing Activity (CUPRAC)}

In order to determine the antioxidant capacity of Trolox equivalent (TEAC), $\mathrm{Cu}$ (II) reduction activity test was performed by CUPRAC (Cupric Ion Reducing Antioxidant Capacity) method. $1 \mathrm{~mL}$ of $10^{-2} \mathrm{M} \mathrm{CuCl}_{2}, 1 \mathrm{~mL}$ of $7.5 \times 10^{-3} \mathrm{M}$ neocuproine and $1 \mathrm{~mL}$ of $1 \mathrm{M}$ $\mathrm{NH}_{4} \mathrm{Ac}$ were placed in a test tube, respectively. These plant extracts were put into tubes at certain concentrations $(10-100 \mu \mathrm{g} / \mathrm{mL})$ and diluted with $\mathrm{dH}_{2} \mathrm{O}$ to $4.1 \mathrm{~mL}$. After the tubes were kept closed for 30 minutes at room temperature, the absorbance values at $450 \mathrm{~nm}$ were measured. Results were expressed as trolox equivalent ( $\mu$ mol trolox/mg extract) antioxidant capacity (TEAC ${ }_{\text {CUPRAC}}$ ) utilizing formula (II) [22].

$$
\mathrm{TEAC}_{\mathrm{CUPRAC}}=\mathrm{A}_{\text {(plant extract })} / \mathrm{A}_{(\text {Trolox })}
$$

$\mathrm{A}_{\text {(plant extract) }}$ and $\mathrm{A}_{\text {(trolox) }}$ in Formula (II) refer to the molar absorption coefficient for plant extract and trolox, respectively.

\subsection{Antimicrobial Activity}

Antimicrobial activity was performed using the MIC (Minimum Inhibitory Concentration) method [23]. Microorganisms were obtained from Ondokuz Mayıs University. Gram positive (Staphylococcus aureus ATCC 6538P, Bacillus cereus ATCC 7064), Gram negative (Escherichia coli W3110, Pseudomonas aeruginosa ATCC 27853) and a yeast (Candida albicans ATCC 10231) were used. Stock solutions of the used extracts were prepared at a concentration of $40 \mathrm{mg} / \mathrm{mL}$. Extracts were dissolved in DMSO. The last tube without bacterial growth was determined as MIC value. MIC values obtained in the study were shown as $\mu \mathrm{g} / \mathrm{mL}$.

\subsection{DNA Interaction}

Determination of the plant extracts effect on plasmid DNA (pBR322) was made according to agarose gel electrophoresis method [24]. For this purpose, 1\% Agarose gel was prepared in TBE (1X) buffer. $120 \mu \mathrm{g} / \mathrm{mL}$ plant extracts were interacted with $0,5 \mu \mathrm{g} / \mathrm{mL} \mathrm{pBR322}$ plasmid DNA at $37^{\circ} \mathrm{C}$ for 2 hours. After incubation samples were mixed with $6 \mathrm{X}$ loading dye and loaded on $1 \%$ agarose gel. Electrophoresis was carried out $100 \mathrm{v}$ for $80 \mathrm{~min}$. The gel, then, was stained with $\mathrm{EtBr}$ (Ethidium Bromide) and the bands were imaged with the aid of the UV transilluminator (Cleaver Clear View). 


\section{RESULTS and DISCUSSION}

Saponins, flavonoids, phenols and tannins are among the secondary metabolites in plants and play an important role in anticancer and antioxidant activities [25-27]. The iridoids, fatty acids and 16 phenolic compounds are isolated from the above and below ground parts of $C$. longiflorus subsp. longiflorus [6-8, 11]. For this, the above-ground and root parts of this taxon are used in the prevention and treatment of diseases such as soothing, antispasmodic, anticholytic, familial hypercholesterolemia, coronary artery disease and colon cancer in traditional Turkish medicine $[10,28]$. On the other hand, scientists have stated that methanol is widely used and it is an effective solvent for the extraction of antioxidants [29, 30].

\subsection{Total Phenolic Compounds}

The standard graph was prepared using gallic acid in order to calculate the total phenolic content and shown in Figure 1. The phenolic contents of above and below-ground extracts were given in Table 1. When total phenolic results of above and below-ground extracts of $C$. longiflorus subsp. longiflorus were examined, above and below-ground methanol extracts were seen to have high total phenolic content. Especially above and below-ground hexane extracts had the lowest total phenolic content compared to other extracts of this subspecies. For this, above and below-ground methanol extracts of studied subspecies may be preferred as natural antioxidant sources in the future.

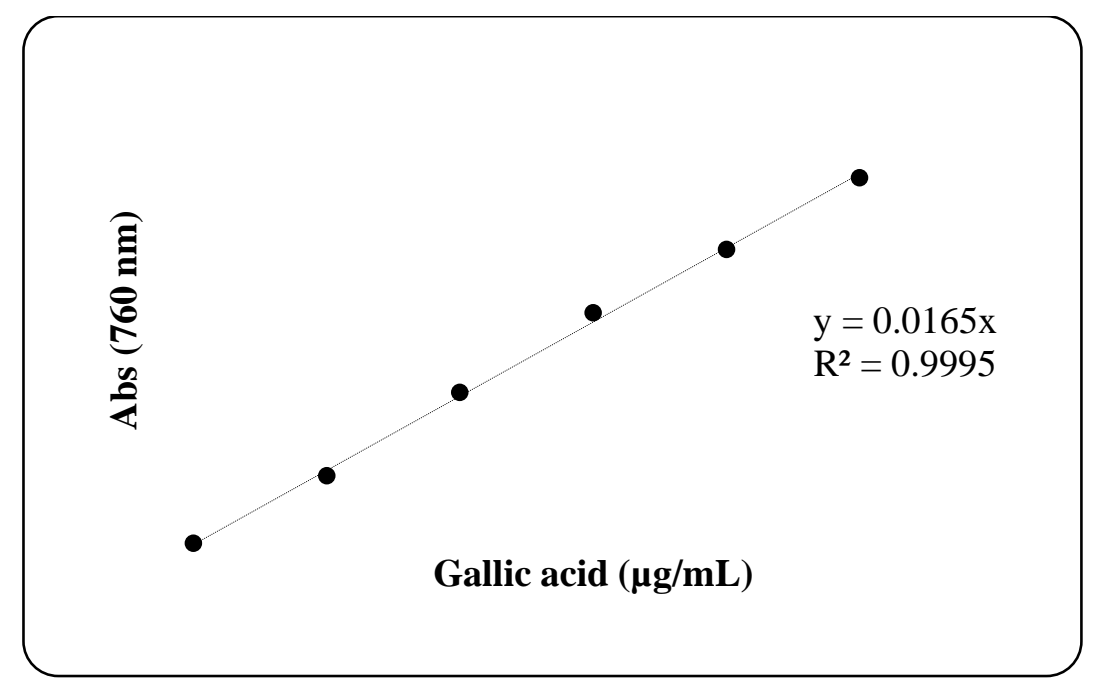

Figure 1. Gallic acid standard graph

\subsection{Free Radical Scavenging Analysis}

The free radical scavenging activity results of the above and below-ground extracts were given in Figure 2 and in Table 2. According to these results, $\mathrm{IC}_{50}$ values of above and belowground hexane extracts could not be calculated since they do not have radical extinguishing capabilities. In particular, $\mathrm{IC}_{50}$ value of the above and below-ground methanol extracts had the highest antioxidant capacity. This situation is related to the high concentration of phenolic compounds in the above and below-ground methanol extracts. Antioxidant activity occurs due to the natural polyphenolic compounds present in plant extracts [31]. The amount of polyphenolic compounds in plants is important, since plants containing high polyphenolic compounds will be important antioxidant sources. We think that above and below-ground methanol extracts of $C$. longiflorus subsp. longiflorus may be used as an antioxidant source. 
Table 1. Phenolic contents of plant extracts

\begin{tabular}{lc}
\hline Plant Extracts & Phenolic contents $(\mu \mathrm{g} \mathrm{GAE} / \mathrm{mL})$ \\
\hline Above-ground hexane & 21.8 \\
Above-ground ethanol & 24.2 \\
Above-ground methanol & 93.9 \\
Below-ground hexane & 18.2 \\
Below-ground ethanol & 38.8 \\
Below-ground methanol & 96.9 \\
\hline
\end{tabular}

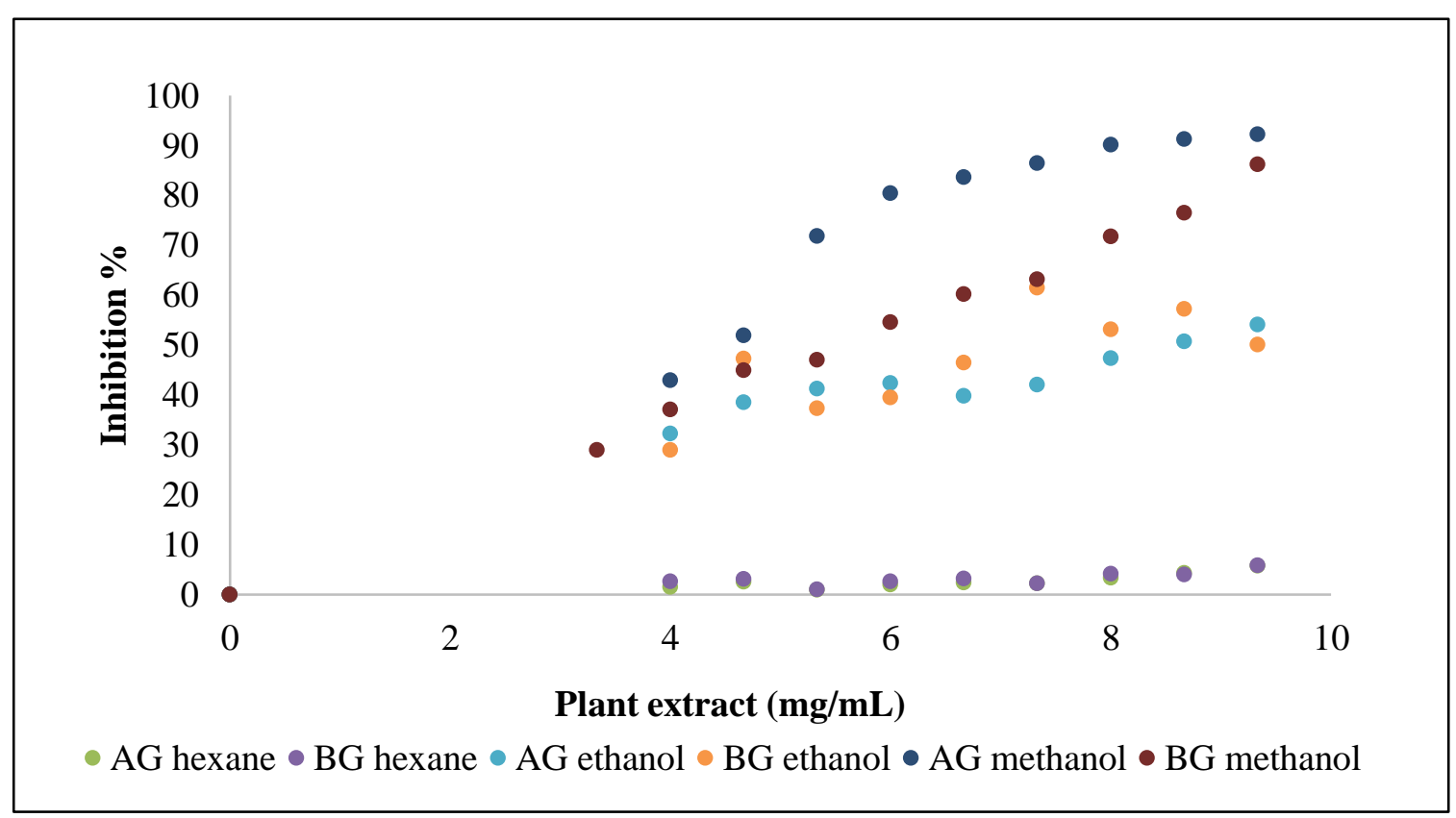

Figure 2. DPPH radical trapping activity. AG: Above-Ground, BG: Below-Ground

Table 2. $\mathrm{IC}_{50}$ values of plant extracts

\begin{tabular}{lc}
\hline Plant Extracts & $\mathrm{IC}_{50}(\mathrm{mg} / \mathrm{mL})$ \\
\hline BHA & 0.019 \\
Above-ground hexane & $*$ \\
Above-ground ethanol & 8.6 \\
Above-ground methanol & 4.5 \\
Below-ground hexane & $*$ \\
Below-ground ethanol & 7.3 \\
Below-ground methanol & 5.7 \\
\hline$*: \mathrm{IC}_{50}$ values of hexane extracts could not be calculated
\end{tabular}

Similar results have been reported in antioxidant studies of Centranthus longiflorus subsp. longiflorus. Namely, Zengin et al. [32] used phosphomolybdenum, free radical scavenging activity and metal chelating activity tests for antioxidant activity of $C$. longiflorus subsp. longiflorus and Cerinthe minor subsp. auriculata (Ten.) Domac extracts. The extracts of both plants were prepared with methanol, ethyl acetate and aqueous. Plant samples of $C$. longiflorus subsp. longiflorus and Cerinthe minor subsp. auriculate collected from Ankara and Afyon vicinity. In particular, C. longiflorus subsp. longiflorus extracts prepared with methanol were determined to show higher antioxidant activity. Zengin et al. [32] reported that $C$. longiflorus subsp. longiflorus and Cerinthe minor subsp. auriculata could be valuable in the 
development of new drug formulations and the preparation of new food supplements. In a study on $C$. longiflorus growing in Lebanon, three different tests (DPPH, $\mathrm{H}_{2} \mathrm{O}_{2}$ and iron chelating) were applied to plant extracts prepared with aqueous and methanol. The tests showed that antioxidant activity in C. longiflorus extracts were $80 \%, 70 \%$ and $50 \%$, respectively [4]. In our study, it was determined that above and below-ground extracts especially prepared with methanol had significant antioxidant activity. Briefly, it is possible to think that the above and below-ground extracts prepared with methanol of this subspecies contain more polyphenols compounds than other extracts. Also, Aliyazioğlu et al. [11] put forward that methanol extracts of $C$. longiflorus showed strong antioxidant activity. In short, our antioxidant results are consistent with antioxidant results of Rammal et al. [4], Aliyazıcıoğlu et al. [11], Zengin et al. [32]. This is due to the use of the same organic solvent and similar antioxidant tests in four studies. Similar antioxidant results were reported in Gagea fibrosa (Desf.) Schulte \& Schultes fil.-leaves methanol extract and Romulea ramiflora Ten subsp. ramiflora-bulb methanol extract by Mammadov et al. [19]. On the other hand, Turan and Mammadov [33] reported the highest antioxidant activity in acetone extracts of Cyclamen alpinum Dammann ex. Springer. Molyneux [34] put forward that phenolic compounds can act as free radical scavengers based on their hydrogen-donating property. The above findings indicate that the antioxidant activity of methanol extract is associated with a high phenolic compound level. On the other hand, it can potentially be used to prevent oxidative stress-related and aging-associated diseases, since this taxon has numerous secondary metabolites and neutralizes free radicals in the body [35]. Aliyazıcıoğlu et al. [11] emphasized that $C$. longiflorus had rich phenolic compositions, antioxidant activities and potential for using as raw materials in the pharmaceutical and food industries in the prevention and treatment of various diseases due to oxidative stress.

In Turkey, antioxidant activities of some plants used in traditional medicine (including Centranthus longiflorus) were investigated by Çoban et al. [36]. Plant samples were collected from Ankara-Kizilcahamam. The above-ground extracts of plant samples were prepared using aqueous and ethanol. The above-ground ethanol extract of $C$. longiflorus was found to have the most potential antioxidant activity. Hence, Çoban et al. [36] reported that the above-ground ethanol extract can be considered as the best antioxidant source. Nevertheless, it is plausible to suggest that the ethanol extracts of this species may contain more polyphenolic compounds, because the polyphenolic compounds were determined to exhibit potent antioxidant activities $[37,38]$. The above and below-ground parts of Heliotropium samolifolium Bunge subsp. erzurumicum Dönmez were extracted in the presence of different organic solvents (hexane, chloroform, ethyl acetate, ethanol, ethanol+aqueous and aqueous). Especially above ground ethanol+aqueous, chloroform and below-ground ethanol extracts of the H. samolifolium subsp. erzurumicum were reported to demonstrate the highest antioxidant activity [39]. In the biological activity studies of the endemic Iris kirkwoodiae Chaudhary, especially aqueous and methanol extracts exhibited very high antioxidant activity [40]. The antioxidant findings of Çoban et al. [36], Sağlam and Kandemir [39], Emaduldeen [40] are compatible with the antioxidant findings of our study. This may be due to the use of similar organic solvents and similar antioxidant methods. Similar organic solvents cause to appear of similar secondary metabolites, although plant species are different.

\subsection{CUPRAC Analysis}

The standard graph of Trolox was shown in Figure 3, the trolox equivalent of plant extracts are given in Figure 4 and in Table 3. The $\varepsilon_{\mathrm{T}}$ value of the trolox was calculated as 1.66 $\mathrm{x} 10^{4} \mathrm{~L} \cdot \mathrm{mol}^{-1} \cdot \mathrm{cm}^{-1}$. In antioxidant studies, $\mathrm{Cu}^{2}+$ reduction is used to determine electron donation activity. According to trolox equivalents, the above and below-ground methanol extracts were found to have high antioxidant activity. Aliyazıcıoğlu et al. [11] used ferric reducing/antioxidant power (FRAP) assay in methanol sample of $C$. longiflorus. Trolox 
equivalent was found to be high in blossom $(114 \mu \mathrm{mol}$ Trolox/100 g DW) and trunk $(156 \mu \mathrm{mol}$ Trolox/100 g DW). In our study, the highest torolox equivalent was seen in above (126 $\mu \mathrm{mol}$ trolox/mg extract) and below-ground $(132 \mu \mathrm{mol}$ trolox/mg extract) methanol extracts. These data were showed parallelism with the results found in other antioxidant methods in our study. Similar $\mathrm{Cu}^{2+}$ reduction (CUPRAC) results were found in gall and leaves ethanol extracts of Andricus quercustozae by Azmaz et al. [41].

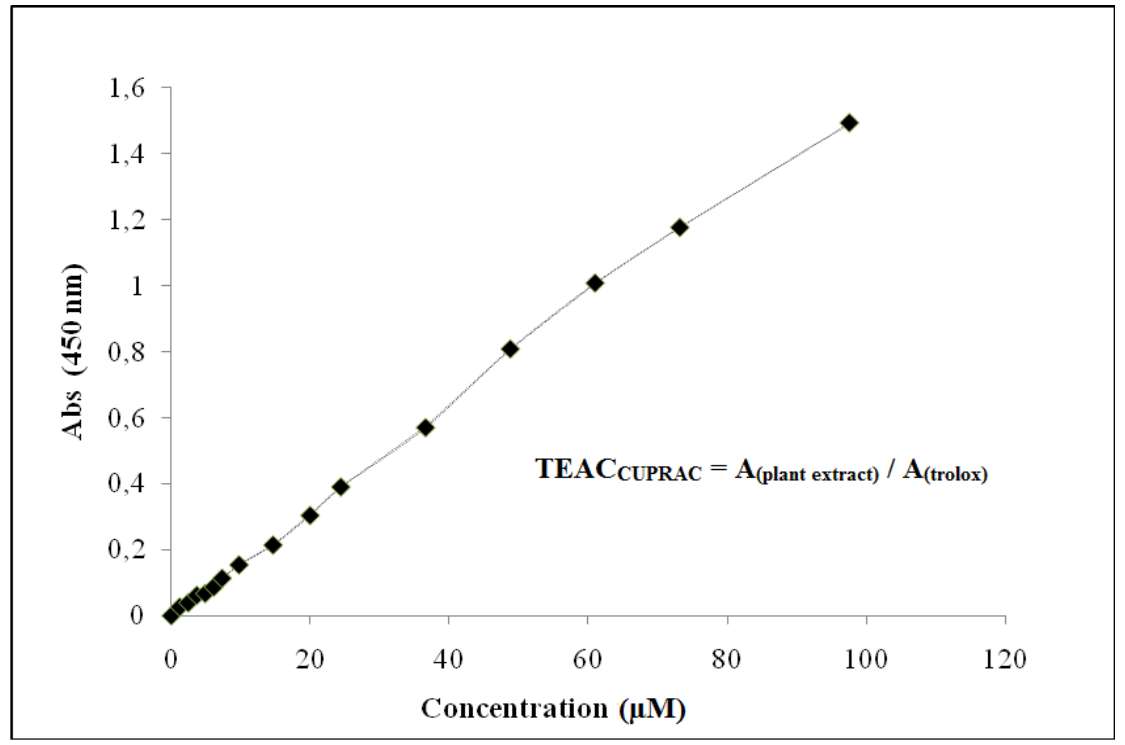

Figure 3. Trolox $\mathrm{Cu}^{2+}$ reduction power graph

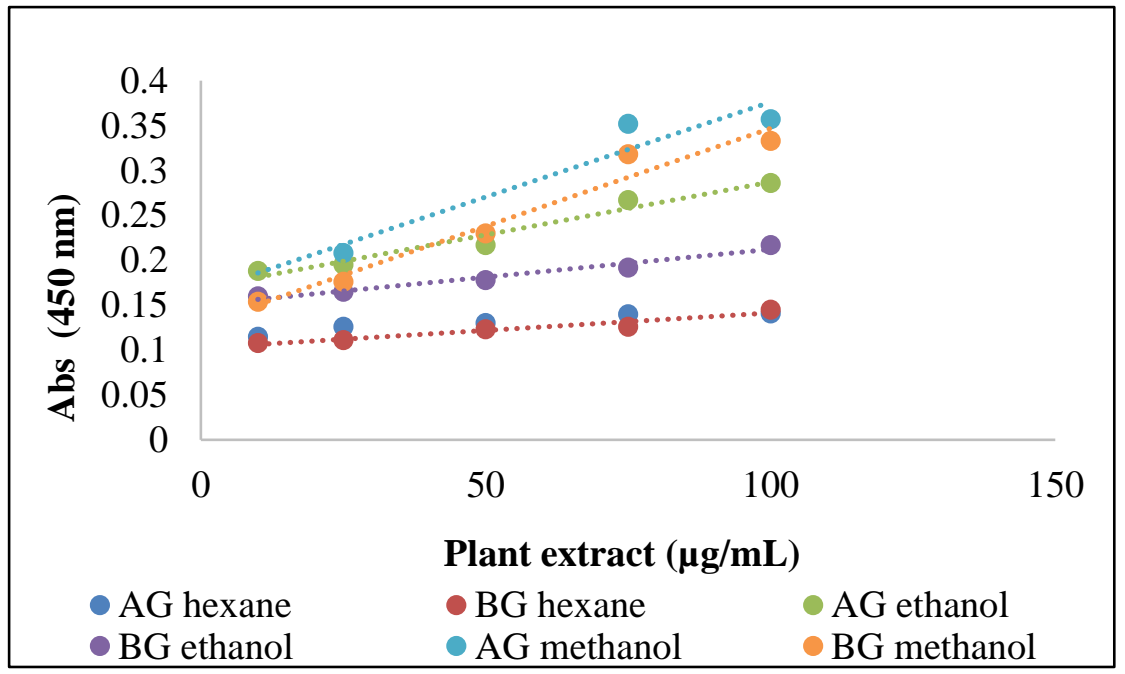

Figure 4. $\mathrm{Cu}^{2+}$ reduction power graph of plant extracts

\subsection{Antimicrobial Analysis}

MIC values of above and below-ground of plant extracts were given in Table 4. The below-ground hexane extract was found to have strong antimicrobial activity on E. coli and $P$. aeruginosa. However, the below-ground hexane extract was observed to show intermediate antimicrobial activity on $B$. cereus and $S$. aureus. The above-ground hexane extract had low antimicrobial activity on E. coli, $P$. aeruginosa and $C$. albicans. Also, the below-ground ethanol extract of this subspecies demonstrated antimicrobial activity on only B. cereus bacterium (Table 4). 
Table 3. Trolox equivalent antioxidant capacity (TEAC CUPRAC $_{\text {) of plant extracts }}$

\begin{tabular}{lc}
\hline \multicolumn{1}{c}{ Plant Extracts } & $\begin{array}{c}\text { TEAC } \\
\mu \text { CUPRAC } \\
\text { Amol trolox/mg extract }\end{array}$ \\
\hline Above-ground hexane & 18 \\
Above-ground ethanol & 72 \\
Above-ground methanol & 126 \\
Below-ground hexane & 24 \\
Below-ground ethanol & 36 \\
Below-ground methanol & 132
\end{tabular}

Table 4. MIC values on different microorganisms of plant extracts $(\mu \mathrm{g} / \mathrm{mL})$

\begin{tabular}{lccccc}
\hline \multicolumn{1}{c}{ Plant extracts } & $\begin{array}{c}\text { Escherichia } \\
\text { coli } \\
\text { (W3110) }\end{array}$ & $\begin{array}{c}\text { Pseudomonas } \\
\text { aeruginosa } \\
\text { (ATCC 27853) }\end{array}$ & $\begin{array}{c}\text { Bacillus cereus } \\
\text { (ATCC 7064) }\end{array}$ & $\begin{array}{c}\text { Staphylococcus } \\
\text { aureus } \\
\text { (ATCC 6538P) }\end{array}$ & $\begin{array}{c}\text { Candida } \\
\text { albicans } \\
\text { (ATCC 10231) }\end{array}$ \\
\hline Above-ground hexane & 1500 & 1500 & 3000 & 3000 & 1500 \\
Below-ground hexane & 375 & 375 & 750 & 750 & 1500 \\
Above-ground ethanol & 3000 & 3000 & 3000 & 3000 & 3000 \\
Below-ground ethanol & 3000 & 3000 & 1500 & 3000 & 3000 \\
Above-ground methanol & 3000 & 3000 & 3000 & 3000 & 3000 \\
Below-ground methanol & 3000 & 3000 & 3000 & 3000 & 3000 \\
\hline
\end{tabular}

Aliyazıoğlu et al. [11] reported that aqueous and methanol extracts of $C$. longiflorus showed strong antimicrobial effect against Mycobacterium smegmatis ATCC607 bacterium. In our study, the strongest antimicrobial activity was seen in below-ground hexane extracts. Especially, below-ground hexane extracts have an activity on the Gram-negative, positive bacteria and yeast used in this study. This effect was seen higher in Gram negative bacteria than Gram positive bacteria. Therefore, it would be more appropriate to prepare an antimicrobial drug on Gram negative bacteria rather than Gram positive bacteria from extracts of this taxon. On the other hand, there are no antimicrobial effects on bacteria of above and below-ground ethanol and methanol extracts except below-ground ethanol. Our antimicrobial results do not match the antimicrobial results of Aliyazıoğlu et al. [11]. Such a case can be attributed to the collection of plant samples from different localities at different times and the use of different antimicrobial methods and different microorganism. Also, Aliyazıcıoğlu et al. [11] have made extraction process without separating above and below ground the plant materials. The aqueous and ethanol extracts of Eryngium creticum Lam. and C. longiflorus distributing in Lebanon were tested with five different bacteria (Staphylococcus epidermidis CIP 444, Staphylococcus aureus ATCC 25923, Enterococcus faecalis ATCC 29212, Escherichia coli ATCC 35218 and Pseudomonas aeruginosa ATCC 27853) by Makki et al. [10]. Aqueous extracts were reported to exhibit strong antibacterial activity in both plants. The reason why Makki et al. [10] and our antimicrobial results are incompatible may be due to the use of different bacterial strains and different organic solvents in the study. Also, this case may be due to the different cell wall structures of Gram-positive and Gram-negative bacteria.

In another antimicrobial research [39], the above and below-ground extracts of $H$. samolifolium subsp. erzurumicum, which distribute around Erzurum, were applied to Gram positive (Staphylococcus aureus ATCC 25923, Micrococcus luteus NRLLB 1018), Gram negative (Escherichia coli ATCC 25922, Pseudomonas aeruginosa ATCC 27853) standard bacterial strains and a yeast (Candida albicans ATCC 10231). All above and below-ground 
extracts of the subsp. erzurumicum except above-ground hexane and above-ground ethanol+aqueous were obtained to show intermediate antifungal activity on $C$. albicans. The below-ground ethanol extract was found to exhibit moderate activity on $S$. aureus, while the below-ground ethanol extract to exhibit stronger antimicrobial activity on $M$. luteus and $P$. aeruginosa. The below-ground ethanol extract of the H. samolifolium subsp. erzurumicum did not have any antimicrobial activity on only E. coli. Our antimicrobial findings do not match with the antimicrobial findings of Sağlam and Kandemir [39]. It is thought that this is due to the use of different plant extracts in the studies. Since different plant extracts have different secondary metabolites, the effects of these metabolites on microorganisms are different.

Anti-proliferative properties of $C$. longiflorus extracts collected from Lebanon were also examined. It was suggested that the leaf and stem parts of this plant had significant antioxidant and anti-proliferative activities, due to the presence of some secondary metabolites (alkaloids, coumarins, saponin, polyphenols, volatile oils, flavonoids) in the leaves and stem of $C$. longiflorus [42]. In a study, sedative, anticonvulsant and behavior modification activities of subsp. longiflorus extracts were investigated. In the effects of aqueous extract $(100 \mathrm{mg} / \mathrm{kg})$ compared with diazepam, aqueous was found to have sedative and anticonvulsant effects similar to those produced by diazepam $(5 \mathrm{mg} / \mathrm{kg})$ [43].

\subsection{DNA Interaction}

The DNA interaction results were shown in Figure 5. 1 and 2 lanes belong to pBR322 $\mathrm{DNA}+\mathrm{H}_{2} \mathrm{O}$ and pBR322 DNA+DMSO control groups, respectively. The extracts of aboveground hexane (Lane 3) and above-ground methanol (Lane 7) had no effect on pBR322 plasmid DNA, while the extracts of the above and below-ground ethanol (Lanes 5 and 6) had the effect of completely eliminating the open ring form. The below-ground methanol extract (Lane 8) had a disintegrating effect on the open ring structure. However, the below-ground hexane extract (Lane 4) was found to have an effect on increasing the concentration of open ring form.

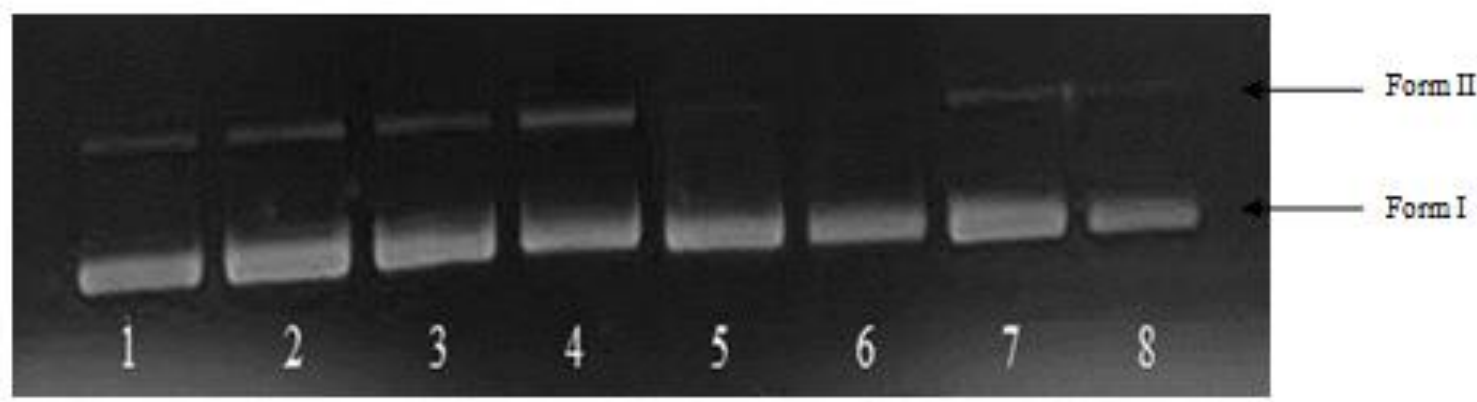

Figure 5. Agarose gel electrophoresis diagram. (Lane 1, 2) pBR322 DNA+ $\mathrm{H}_{2} \mathrm{O}$, pBR322 DNA+DMSO control; (Lane 3, 4) pBR322 DNA+AG, pBR322 DNA+BG hexane extract; (Lane 5, 6) pBR322 DNA+AG, pBR322 DNA+BG ethanol extract; (Lane 7, 8) pBR322 DNA+AG, pBR322 DNA+BG methanol extract.

In a DNA interaction study, the below and above-ground chloroform and aqueous, aboveground hexane, below-ground ethyl acetate, ethanol extracts of endemic $H$. samolifolium subsp. erzurumicum showed a destructive effect to the structure of pBR322 plasmid DNA [39]. In the biological activity studies of the endemic Iris kirkwoodiae, all extracts except root dichloromethane and aqueous extracts showed protection for plasmid DNA against UV and $\mathrm{H}_{2} \mathrm{O}_{2}$ [40]. In another DNA interaction study, samples of endemic Iris galatica Siehe. were extracted with hexane, methanol dichloromethane and aqueous, all of the plant extracts were found to protect DNA against the harmful effects of UV and $\mathrm{H}_{2} \mathrm{O}_{2}$ [44]. Also, below-ground 
ethanol extracts of Leucojum aestivum L. were displayed highly effect on pBR322 plasmid DNA [45]. In a similar study with endemic Linaria corifolia Desf., the above and below-ground ethanol, ethyl acetate and dichloromethane extracts were determined to show protective activity on plasmid DNA [46]. The plasmid DNA results of the mentioned-above studies are compatible with plasmid DNA results in our study.

\section{CONCLUSION}

Some biological and antioxidant activities of extracts of $C$. longiflorus subsp. longiflorus collected from the vicinity of Tortum (Erzurum) were determined. According to our antioxidant results, both above and below-ground methanol extracts can be used as antioxidant source in many areas. Our antimicrobial data showed that the below-ground hexane extracts of this plant may be added in the content of drugs used in the treatment of diseases Gram-positive and negative bacteria, yeast borne. In addition, above-ground hexane extracts can be included into the structure of drugs for the treatment of Gram negative and yeast diseases. Especially, the above and below-ground ethanol extracts of investigated subspecies were seen to have significant effect on pBR322 plasmid DNA. Briefly, above and below-ground hexane, methanol and ethanol extracts of this plant may be used in many areas of the pharmaceutical industry. Although there are some studies related to this subspecies, this study will contribute to other studies in this field as a new literature source. The study on DNA damage was done by us for the first time.

\section{Acknowledgements}

This study was produced within the scope of the project of FMB-BAP 14-073 supported by Amasya University. This study is derived from master thesis Elif Ayar's. "Comparison of antioxidant and antibacterial effects of Centranthus longiflorus ssp. longiflorus plant extracts prepared in different solvents, XII. National Ecology Congress, 14-17 September 20150". The mentioned article was presented at this congress and only the abstract section was published in the abstract booklet of this congress.

\section{Declaration of Conflicting Interests and Ethics}

The authors declare no conflict of interest. This research study complies with research publishing ethics. The scientific and legal responsibility for manuscripts published in IJSM belongs to the author(s).

\section{Orcid}

Elif Ayar (D) https://orcid.org/0000-0001-9281-1545

Nezahat Kandemir (D) https://orcid.org/0000-0002-5428-4139

Sevket Kandemir (iD https://orcid.org/0000-0001-6781-0057

Umut Celikoglu (D) https://orcid.org/0000-0003-0995-8154

Onder Idil (D) https://orcid.org/0000-0003-1744-4006

\section{REFERENCES}

[1]. Güner, A. (2012). Centranthus DC. In List of Turkey Plants (Vascular Pants), ed.; Aslan, S., Ekim, T., Vural, M., Babaç, M.T.; Publication of Nezahat Gökyiğit Botanic Garden and Floristic Research Society: İstanbul, Turkey, pp. 314. ISSN:978-605-60425-7-7.

[2]. Baytop, T. (1999). Used Medicine Plants in Turkey. In Therapy with Plant in Turkey (Past and Present). Ed.; Baytop, T.; Nobel Medicine Bookstores: İstanbul, Turkey, 975-420021-1.

[3]. Rice-Evans, C., Miller, A., Paganga, G. (1997). Antioxidant Properties of Phenolic Compounds. Trends Plant Sci., 2, 152-59. https://doi.org/10.1016/SI3601385(97)01018-2 
[4]. Rammal, H., Farhan, H., Hijazi, A., Bassal, A., Kobeissy, A., Badrtan, B. (2013). Phytochemical Screening and Antioxidant Activity of Centranthus longiflorus L. J. Nat Prod Plant Resour., 3, 29-36.

[5]. Wong, C.C., Li, H.B., Cheng, K.W., Chen, F. (2006). A systematic survey of antioxidant activity of 30 Chinese medicinal plants using the ferric reducing antioxidant power assay. Food Chem., 97, 705-711. https://doi.org/10.1016/j.foodchem.2005.05.049

[6]. Sener, B., Mutlugil, A., Bingöl, F. (2008). Analysis of valepotriates in Centranthus longiflorus Stev. by reversed-phase high pressure liquid chromatography. Pharm Biol., 25, 133-136. https://doi.org/10.3109/13880208709060916

[7]. Demirezer, L.Ö., Güvenalp, Z., Schiewe, H.J., Strietzel, I., Harmandar, M., Zeeck, A. (1999). Iridoids from Centranthus longiflorus ssp. longiflorus. Phytochemistry, 51, 909912. https://doi.org/10.1016/s0031-9422(99)00152-1

[8]. Kuruüzüm, A-Uz., Güvenalp, Z., Demirezer, L.Ö., Bergere, I., Stroch, K., Zeeck, A. (2002). 4-deoxy iridoid glycoides from Centranthus longiflorus. Phytochemistry, 61, 937941. https://doi.org/10.1016/S0031-9422(02)00476-4

[9]. Hassan, E., Tayebeh, R., Samaneh, E.T. (2008). Quantification of Valerenic Acid and its derivatives in some species of Valeriana L. and Centranthus longiflorus Stev. Asian J. Plant Sci., 7, 195-200. https://doi.org/10.3923/ajps.2008.195.200

[10]. Makki, R., Dirani, Z. E., Rammal, H., Sweidan, A., Al Bazzal, A., Chokr, A. (2015). Antibacterial Activity of Two Lebanese Plants: Eryngium creticum and Centranthus longiflorus. J. Nanomed. Nanotechnol., 6, 315-320. https://doi.org/10.4172/2157-7439.1000315

[11]. Aliyazıcıoğlu, R., Korkmaz, N., Akkaya, S., Sener, S.Ö., Badem, M., Karaoğlu, S.A., Eyüpoğlu, O.E. (2016). Phenolic components, antioxidant and antimicrobial activities of Centranthus longiflorus L. Int. J. Adv. Res. Biol. Sci., 3, 80-87. https://doi.org/10.22192/ijarbs.2016.03.10.012

[12]. Cowan, M.M. (1999). Plant Products as Antimicrobial Agent. Clin microbiol Rev., 12, 564-582. https://doi.org/10.1128/CMR.12.4.564

[13]. Okunade, A.L., Elvin-Lewis, M.P.F. (2004). Natural Antimycobacterial Metabolites: Current Status. Phytochemistry, 65, 1017-1032. https://doi.org/10.1016/j.phytochem.2004.02.013

[14]. Taguri, T., Tanaka, T., Kouno, I. (2004). Antimicrobial Activity of 10 Different Plant Polyphenol Against Bacteria Causing Food-Borne Disease. Biol Pharm Bull., 27, 19651969. https://doi.org/10.1248/bpb.27.1965

[15]. Cheesman, L., Nair, J.J., Van Staden, J. (2012). Antibacterial Activity of Crinane Alkaloids From Boophone disticha (Amaryllidaceae). J Ethnopharmacol., 140, 405-408. https://doi.org/10.1016/j.jep.2012.01.037

[16]. Topal, Y. (2013). Investigation of Antioxidant and Antimicrobial Effects of Phenolic Compounds of Some Species of Alchemilla L. (Rosaceae) genus. Master thesis, Institute of Science and Technology, Bingöl University, Bingöl, Turkey.

[17]. Kawanishi, S., Hiraku, Y. (2004). Amplification of anticancer drug-induced DNA damage and apoptosis by DNA-binding compounds. Curr Med Chem-Anticancer 
Agents, 4(5), 415-419.

https://doi.org/10.2174/1568011043352867

[18]. Richardson, I.B.K. (1972). Centranthus DC. In Flora of Turkey and The East Aegean Islands, 4th ed.; Davis, H.P., Chamberlain, D.F., Phil, D., Victoria, A., Matthews, B.; Edinburgh University Press: Edinburg, England, Volume 4, pp. 558-559; ISSN:0852242085

[19]. Mammadov, R., Ili, P., Vaizoğullar, H.E., Makasçı, AA. (2011). Antioxidant Activity and Total Phenolic Content of Gagea fibrosa and Romulea ramiflora. Iran J. Chem. Chem. Eng., 30, 57-62.

[20]. Singleton, V.L., Rossi, J.A. (1965). Colimetry of total phenolics with phosphomolybdicphosphotungstic acid reagents. Am J Enol Vitic., 16, 144-158.

[21]. Brand-Williams, W., Cuvelier, M.E., Berset, C. (1995). Use of a free radical method to evaluate antioxidant activity. LWT-Food Sci Technol., 28, 25-30. https://doi.org/10.1016/S0023-6438(95)80008-5

[22]. Apak, R., Güçlü, K., Özyürek, M., Karademir, S.E. (2004). A novel total antioxidant capacity index for dietary polyphenols, Vitamin $\mathrm{C}$ and $\mathrm{E}$, using their cupric ion reducing capability in the presence of neocuroine: CUPRAC method. J. Agric. Food Chem., 52, 7970- 7981. https://doi.org/10.1021/jf048741x

[23]. Andrews, J.M. (2001). Determination of minimum inhibitory concentrations. $J$ Antimicrob Chemother., 48, 5-16. https://doi.org/10.1093/jac/48.suppl._1.5

[24]. Babu, J., Pramod, W.R., George, T., Nitisha, S. (2007). Standard Review Cold-active microbial Lipases: a versatile tool for industrial applications. Biotechnol. Mol. Biol. Rev., 2, 39-48.

[25]. Wink, M., Ashour, M.L., El-Readi, M.Z. (2012). Secondary Metabolites from Plants Inhibiting ABC Transporters and Reversing Resistance of Cancer Cells and Microbes to Cytotoxicand Antimicrobial Agents. Front Microbiol., 3, 130. https://doi.org/10.3389/fmicb.2012.00130

[26]. Law, P.C., Auyeung, K.K., Chan, L.Y., Ko, J.K. (2012). Astragalus Saponins Downregulate Vascular Endothelial Growth Factor Under Cobalt Chloride-Stimulated Hypoxia in Colon Cancer Cells. BMC Complement Altern Med., 12, 160. https://doi.org/10.1186/1472-6882-12-160

[27]. Zamora-Ros, R., Agudo, A., Luján-Barroso, L., Romieu, I., Ferrari, P., Knaze, V., Sánchez-Cantalejo, E., et al. (2012). Dietary Flavonoid and Lignan Intake and Gastric Adenocarcinoma Risk in The European Prospective Investigation into Cancer and Nutrition (EPIC) study. Am J Clin Nutr., 96, 1398-1408.

https://doi.org/10.3945/ajen.112.037358

[28]. Süleyman, H., Güvenalp, Z., Kızılkaya, M., Demirezer, Ö.L. (2007). Sedative effect of Centranthus longiflorus ssp. longiflorus in rats and the influence of adrenalectomy on its effect. Yakugaku Zasshi., 127, 1263-1265. https://doi.org/10.1248/yakushi.127.1263.

[29]. Hassan, R., Hussein, F., Akram, H., Ali, B., Ahmed, K., Bassam, B. (2013). Phytochemical Screening and Antioxidant Activity of Centranthus longiflorus. L. J. Nat. Prod. Plant Resour., 3, 29-36.

[30]. Yen, G.C., Wu, S.C., Duh, P.D. (1996). Extraction and Identification of Antioxidant Components from The Leaves of Mulberry (Morus alba L.). J. Agric. Food Chem., 44, 1687-1690. https://doi.org/10.1021/jf9503725

[31]. Yılmaz, A., Yıldız, S., Tabbouche, S., Kılıç, A.O., Can, Z. (2016) Total Phenolic Content, Antioxidant and Antimicrobial Properties of Pleurotos ostreatus Grown on Lime (Tilia tomentosa) Leaves. Hacettepe J. Bio and Chem, 44, 119-124. https://doi.org/10.15671/HJBC.20184417585 
[32]. Zengin, G., Nithiyanantham, S., Locatelli, M., Ceylan, R., Uysal, S., Aktumsek, A., Palaniswamy, K., Maskovic, P. (2016). Screening of In vitro Antioxidant and Enzyme Inhibitory Activities of Different Extracts from Two Uninvestigated Wild Plants: Centranthus longiflorus subsp. longiflorus and Cerinthe minor subsp. auriculata. Eur. J. Integr., 8, 286-292.

https://doi.org/10.1016/j.eujim.2015.12.004

[33]. Turan, M., Mammadov, R. (2018). Antioxidant, Antimicrobial, Cytotoxic, Larvicidal and Anthelmintic Activities and Phenolic Contents of Cyclamen alpinum. Pharmacol Pharm., 9, 100-116. https://doi.org/10.4236/pp.2018.94008

[34]. Molyneux, P. (2004). The use of the stable free radical diphenylpicryllhydrazyl (dpph) for estimating antioxidant activity. Songklanakarin J. Sci Technol., 26, 211-219.

[35]. Balunas, M., Douglaskinghorn, AD. (2005). Drug discovery from medicinal plants. Life Sci., 78, 431-441. https://doi.org/10.1016/j.lfs.2005.09.012

[36]. Çoban, T., Saltan, ÇG., Sever, B., İşcan, M. (2003). Antioxidant activities of plants used inTraditional Medicine in Turkey. Pharm. Biol. 41, 608-613. https://doi.org/10.1080/13880200390501974

[37]. Hasanaki, Y., Ogawar, S., Fukui, S. (1994). The correlation between active oxygen species and antioxidative effects of flavonoids. Free Radic Biol Med., 16, 845-850. https://doi.org/10.1016/0891-5849(94)90202-X

[38]. Sanz, MJ., Ferrandiz, M., Cejudo, M., Terencio, MC., Gil, B., Bustos, G., Ubeda, A., Gunasegara, R., Alcanaz, MJ. (1994). Influence of a series of natural flavonoids on freeradical generating systems and oxidative stress. Xenobiotica, 24, 689-699. https://doi.org/10.3109/00498259409043270

[39]. Sağlam, G., Kandemir, N. (2020). Comparison of Biological and Antioxidant Activities of Above and Below-Ground Extracts of Endemic Heliotropium samolifolium subsp. erzurumicum. KSU J. Agric. Nat., 23, 1054-1063. https://doi.org/10.18016/ksutarimdoğa.vi.672571

[40]. Emaduldeen, A. (2014). Investigation of Biological Activities of Iris kirkwoodii. Master Thesis, Gaziantep University, Institute of Science and Technology, Gaziantep, 2014.

[41]. Azmaz, M., Aksoy, Ö.K., Katılmış, Y., Mammadov, R. (2020). Investigation of the Antioxidant Activity and Phenolic Compounds of Andricus quercustozae Gall and Host Plant (Quercus infectoria). Int. J. Second. Metab., 7, 77-87. https://doi.org/10.21448/ijsm.674930

[42]. Makki, R., Rammal, H., Farhan, H., Nasser, M., Dirani, El Z., Hijazi, A. (2015). The antioxidant and anti-tumor activity of the Lebanese Centranthus longiflorus L. World J. Pharm. Sci., 3, 347-354.

[43]. Büyükokuroğlu, M.E., Demirezer, L.O., Güvenalp, Z. (2002). Sedative, Anticonvulsant and Behaviour Modifying Effects of Centranthus longiflorus ssp. longiflorus: A Study of Comparison to Diazepam. Pharmazie, 57, 559-561.

[44]. Orhan, E. (2015). Investigation of Biological Activities of Endemic Iris galatica. Master Thesis, Gaziantep University, Institute of Science and Technology, Gaziantep, 2015.

[45]. Hundur, Ö.D., İdil, Ö., Kandemir, N., Gül, M., Konar, V. (2018). Phytochemical Screening and In vitro Antioxidant, Antimicrobial Activity and DNA Interaction of Leucojum aestivum. Fresen Environ Bull., 27, 6704-6710.

[46]. Gül, M., Öztürk, Çalı, I., Cansaran, A., Idil, O., Kulu, I., Çelikoglu, U. (2017). Evaluation of Phytochemical Content, Antioxidant, Antimicrobial Activity and DNA Cleavage Effect of Endemic Linaria corifolia Desf. (Plantaginaceae). Cogent Chem., 3, 1-14. https://doi.org/10.1080/23312009.2017.1337293 